\title{
Labour exploitation of non-EU migrants in Slovakia: patterns, implications and structural violence
}

Matej Blazek

\begin{abstract}
Very little research has focused on the livelihood of migrants in East/Central Europe. This chapter draws on a national-scale study of non-EU adult migrants' experiences with violence, abuse and exploitation in Slovakia, concentrating on the patterns, extent and socio-legal context of labour exploitation of migrants, particularly from Ukraine and East Asia. Slovakia is significant as an example of labour exploitation in countries with small and overlooked migrant communities. Exploring links between exploitation at the workplace and other forms of violence and abuse at home and in public, the chapter draws on the concept of structural violence, determined by a structural positionality, to explain the complex vulnerability of such migrants.
\end{abstract}

\section{Introduction}

Writing a few years after the countries of East and Central Europe joined the EU in 2004, Castles and Miller (2009:116) named them ‘future immigration lands'. Fuelled by the opening of new labour markets and dynamic economic growth, the number of migrants in Slovakia skyrocketed from 22,108 in 2004 to 73,783 in 2014 (ADP, 2014) although, as with its neighbours, Slovakia still retains one of the very smallest populations of migrants in the EU in both absolute and relative numbers. Small numbers and their peripheral position in 
European migration flows are among the key reasons why the focus on migration in postsocialist European countries concentrates instead on the East-West flows of labour migrants (Burrell, 2009), and, to a lesser extent, on their return (White, 2014).

The chapter evaluates experiences of non-EU migrants in Slovakia with labour-related vulnerability, building on a pioneering national-scale study of the International Organization for Migration (IOM) conducted in 2012 (see Blazek et al., 2013; Blazek, 2014). Exploring migrants' experiences of exploitative labour in a country such as Slovakia adds to the existing understandings of migrant labour in two ways. First, rare empirical data from an East-Central European region indicate patterns of migration, migration policy and migration politics that produce configurations of migrant workers’ vulnerability similar to and simultaneously different from the known dynamics in Western Europe and elsewhere. Whilst distinctive in many ways, Slovakia represents several traits of migration dynamics characteristic of the majority of post-socialist countries but not of Western Europe: small but increasing numbers of migrants, historical experience of ethnic homogeneity (Zubrzycki, 2001), lack of research on migrant communities (Blazek, 2014) and utilitarian migration policies driven by an antagonistic mixture of political populism and EU pressure (Vermeersch, 2005).

As the chapter builds on a wider research project concerned with various forms of violence, abuse and exploitation, it also looks at intersections of labour exploitation and other forms of marginalisation of some migrant groups, such as their exposure to violence in public spaces and to abuse at home. The socio-legal and institutional context of migration and the configurations of some migrant communities are shown to create conditions for a form of wider structural violence (Galtung, 1975) that embeds labour exploitation as one of its 
elements.

The chapter reviews patterns of migration, migration policy and politics in Slovakia, focusing on the importance of work in the lives of non-EU migrants, addressing especially migrants from Ukraine and East Asia as groups most exposed to work exploitation. It outlines key data on migrants' experiences of labour exploitation and explains the underlying factors through a discussion of background policy and legal contexts. It reveals the intersections of migrants’ experiences with other forms of violence and abuse, theorising the complexity of vulnerability as a structural condition.

All unreferenced primary data in the chapter come from the aforementioned IOM study (Blazek et al., 2013) drawing on 690 questionnaires across all non-EU migrant groups in Slovakia, followed by 83 interviews with individual migrants as well as key stakeholders from organisations working with migrants.

\section{Migration in Slovakia: migrant workers, migration policy and politics}

\section{Migration to Slovakia}

The structure of migration flows and the construction of migrants' positionalities as workers located in complex patterns of labour-related inequality and oppression are inter-related (McDowell, 2008). In contrast with most other countries where labour exploitation of migrants has been recorded and explored, especially in Europe, the intensity of migration to Slovakia has been relatively low and its patterns less complex, creating conditions for a distinctive character of migrant communities and migrants’ labour. 
Migration to Slovakia after 2004 has been shaped by three key trends: decreasing numbers of undocumented migrants, low numbers of refugees granted asylum, and slow growth and changing structure of the overall migrant population. The number of recorded illegal bordercrossings or stays decreased by 90\% between 2004 and 2013 (IOM, 2014), mainly as an effect of increased border security after the accession to the EU in May 2004 and the Schengen Area in December 2007. The number of asylum claims also decreased significantly, from 11,395 in 2004 to 441 in 2013 (APD, 2014) and Slovakia consistently records some of the lowest numbers of those granted asylum: less than $3 \%$ of asylum seekers in 2013 were granted an actual refugee status, less than any other EU country except for Malta and Greece (Eurostat, 2014).

As such, migrants who stay in Slovakia are predominantly documented, and their numbers have been constantly rising. However, the figures presented above are boosted particularly by EU citizens, whose proportion went up from 49\% of all migrants in 2004 to 63\% in 2013 (IOM, 2014).Thirty-eight percent of all migrants come from only four post-socialist EU countries: the Czech Republic, Hungary, Romania and Poland (APD, 2014). Ukraine maintains the highest and constantly growing numbers, increasing from 4,007 documented migrants outside the EU in 2004 to 7,137 in 2014. However, Ukrainians represent also the largest group of overstayers (Mrlianová et al., 2011), a significant feature of their likely marginalisation in the labour context, discussed below. The numbers of another key group of non-EU migrants from East and South East Asia (mainly Vietnam, China and South East Korea) rose dramatically between 2004 and 2009, but this growth decelerated since the recession in 2009. 
King (2008) warns that a comparatively smaller size of migrant population does not necessarily result in homogeneous experiences, and that letting countries with smaller numbers of migrants fly 'under the radar' might lead to overlooking substantial levels of vulnerability and marginalisation. As will be shown below, the size of migrant communities in Slovakia is a relevant factor in generating vulnerability, because it impacts on power relations within migrant communities as well as between migrants and institutions.

\section{Non-EU migrants and work}

Although the number of legally working migrants has decreased over the last five years and just over 6,000 non-EU migrants had work permits in 2013, the proportion of adult non-EU migrants who declared any experience with work (documented or not) in the IOM research was 70\%. For migrants from the six most prominent non-EU countries of origin in Slovakia (Table 1), work is the primary motivation for migration for four - only migrants from Serbia and Russia named other factors as more important, mainly family or studies.

Whereas $46 \%$ of all non-EU migrants indicated that work was their reason to come to the country, this number was 58\% for South Koreans, $69 \%$ for Chinese, $70 \%$ for Ukrainians and 75\% for Vietnamese. These groups also illustrate contrasting patterns of work in migrant communities in Slovakia. Korean migrants, for instance, almost exclusively worker in middle and high managerial positions in Korean companies in Slovakia (especially the KIA factory in Žilina). The number of Korean migrants increased ten times between 2004 and 2010 because of investment after Slovakia joined the EU. Only men are usually economically active but unlike other labour migrants from Asia, they often come with their families (27\% of Koreans were younger than 18 in 2010, considerably more than $17 \%$ of migrants from 
China and 11\% from Vietnam) who are involved in social and cultural activities within their spatially and socially segregated communities. By contrast, migrants from China and Vietnam are mainly active in trade and restaurant businesses (see also Baláž and Williams, 2005) and most of them are in the productive age, joining established businesses of their relatives and acquaintances as a temporary or permanent workforce. Whilst a smaller number of Vietnamese migrants came to Slovakia before 1989 as students and their ties with the Slovak population are relatively strong, the majority of Chinese and Vietnamese migrants live in compact and isolated communities, often sharing accommodation with other coworkers who might or might not be family members. Younger adult migrants without families make up the majority of the workforce.

Table 1: Key groups of non-EU migrants in Slovakia according to the country of origin at 30.6.2014 (source: Alien Police Department /APD/, 2014)

\begin{tabular}{|l|l|l|}
\hline Rank & Country of origin & Number of migrants \\
\hline 1. & Ukraine & 7137 \\
\hline 2. & Serbia & 4261 \\
\hline 3. & Russia & 2748 \\
\hline 4. & Vietnam & 2105 \\
\hline 5. & China & 1957 \\
\hline 6. & South Korea & 1556 \\
\hline 7. & US & 850 \\
\hline 8. & Macedonia & 678 \\
\hline
\end{tabular}




\begin{tabular}{|l|l|l|}
\hline 9. & Turkey & 389 \\
\hline 10. & Israel & 275 \\
\hline
\end{tabular}

Migrants from Ukraine are a distinct group and the only one of the four countries with constantly, albeit slowly, increasing numbers, even after the onset of the economic recession. They form a relatively diverse group with regards to work experience. Some come to study, others with their families. Yet, most migrants from Ukraine come to Slovakia for work, utilising information from their relatives or (informal) work agents operating in Ukraine, and their stay in the country is largely opportunistic, depending on availability of work. Unlike Asian migrants, most Ukrainians speak quite good Slovak and their physical appearance is not distinctive. Hence, they are more likely to engage without drawing attention. Relatively few Ukrainians run their own businesses and they usually work (documented or not) for Slovak employers in warehouses, restaurants or at construction sites. However, the recruitment is usually organised collaboratively by powerful members of Ukrainian community and their Slovak partners, such as recruiters, gangmasters or lawyers. Similarly to Chinese and Vietnamese migrants, Ukrainians often leave their families at home (25\% of Ukrainian men and 15\% of women stated they lived separately from their children) and share accommodation arranged by their labour providers. The proportion of Ukrainians who declared work experience in Slovakia was over 80\%, highlighting its significance in their lives.

\section{Migration policy and politics}

The current Migration Policy of the Slovak Republic (2011-2020) was adopted in 2011. For the first time, the country declared a commitment to 'active' migration management with a 
focus on high-skilled labour migration. Whilst the government declared support to migrants in areas such as education, entrepreneurship, health care and legal support, the focus on highskilled migrants overlooked entirely the majority of migrants from the non-EU cohort. In addition, the policy declared a preference for ‘culturally associated countries’ of origin (meaning the white Western world), publicly interpreted by the Minister of Interior as a security measure and a step towards preventing segregation and tensions, citing the 'obvious failures of multiculturalism’ as a rationale for the strategy (Chudžíková, 2011a). The second current relevant framework, the Integration Policy of the Slovak Republic, was adopted by the government in 2014, after previous integration policies were criticised heavily for their lack of accountability, implementation and monitoring mechanisms, and for the transfers of responsibility to non-state actors (Chudžíková, 2011b), The country scores particularly low in international comparative policy indicators such as Migrant Integration Policy Index (www.mipex.eu). While the framework itself was widely considered as an improvement on previous documents, it faced criticism during the public negotiation process because of the persistent lack of effective implementation.

Despite progress in the policy area, the predominant political discourse about migration is still dominated by narratives of security, control and assimilation (Chudžíková, 2011a; Blazek et al., 2013). Similar to other post-socialist countries, the approach to migration management is based on an uneasy combination of political populism that frequently embraces xenophobic tendencies, alongside formal commitments to the EU calling for promigration policies (Vermeersch, 2005; Cerna, 2013). The majority of state funding is allocated to institutions regulating migration, with EU programmes being the predominant source of funding for activities supporting migrants (Blazek, 2014). For migrant workers from outside the EU, it means that individual local contacts (especially intimate partners) or 
the community of their compatriots are key sources of information and resilience as the state fails to engage beyond its policing agenda; in fact, $36 \%$ of non-EU migrants declared that they had never asked any formal institution for help.

\section{Migrants in Slovakia and labour exploitation}

\section{Background to labour exploitation: institutions, policies and law}

Work is the very key element in many non-EU migrants' lives in Slovakia, particularly those who come from Ukraine and Asia. Migrant workers with little awareness of their rights are dependent on informal contacts from their community to arrange not just their work but often also accommodation, food, transport or health care (cf. Scott et al., 2012). Apart from the lack of outreach mechanisms and engagement between migrant communities and the state, another factor is the importance of the Slovak language in communication with institutions and for securing the necessary legal status and protection (Blazek, 2014).

There are differences between such arrangements in the Asian and Ukrainian communities. Much evidence exists about the deliberate and systematic exploitation of Ukrainian workers by their compatriots in collaboration with Slovak employers and agents. On the other hand, poor work conditions in Chinese or Vietnamese workplaces are often a result of the marginalisation of the employers themselves, as they lack the social and economic rights of Slovak citizens (see Wilkinson, 2014), and vulnerability is reproduced, rather than imposed.

No public institution in Slovakia currently actively addresses the labour exploitation of migrant workers or their rights. The focus of both immigration and regular police is on 
enforcing laws and policies rather than support, and there are indications of corrupt activities in the past. An illustration is the practice explained by a research participant from Ukraine who had overstayed and worked illegally in Slovakia for more than ten years. He used to carry a 50-euro banknote in his passport in case is stopped by the police, calling it his 'business card'. The work of Labour Inspection is focused on the detection of undocumented labour with an emphasis on prosecuting the employers and especially the workers, rather than providing support to victims. Migrant entrepreneurs, especially petty traders from East and Southeast Asian communities, declared their perception of systematic harassment by the Inspectorate. No trade unions or similar organisations are active in supporting migrants in Slovakia, unlike some partners in Western Europe (Krings, 2009).

However, it is the legislation and in particular its implementation that fundamentally limits opportunities to tackle exploitative and forced labour. First, immigration law is in practice given priority over labour law, so a victim of labour exploitation without valid work permit is seen first as an illegal immigrant and rather than a victim of crime. This is illustrated by the case of a restaurant owner, confidentially reported by a research participant. The owner was recruiting workers from India but never arranged necessary work documents for them. He stopped paying their salary soon after they arrived and when their discontent was too difficult to handle, he would report them to the police himself, after getting rid of any tangible evidence that they had worked for him, repeating this tactic several times. While victims of human trafficking or 'extremely exploitative labour' can be offered 'tolerated stay', a temporary form of permit and itself a transposition of the EU legislation (Directive 2009/52/EC), this is in practice very rare for victims of human trafficking and hasn't happened for victims of exploitative labour yet. 
'Second, the condition for recognising the worker's status and rights is a legally valid work contract written in the Slovak language (see Dwyer et al., 2011). Thirty-three percent of nonEU migrants declared to the IOM that their understanding of the language was limited or non-existing and only $29 \%$ that their level of Slovak was very good. A common practice in some sectors was then to provide only verbal contracts, in languages other than Slovak neither is a valid document but migrants are usually unaware of it - or differing versions of contracts in different languages. The last option is particularly sophisticated, because the employer retains a valid contract document in Slovak and does not employ the worker illegally. An example of this was a case of Thai masseuses with little knowledge of English and no knowledge of Slovak, who signed eight-hour contracts in both languages. The employer interpreted this to them as eight paid hours of actual massaging, whereas they spent well over ten hours per day at work.

Slovakia lacks a number of mechanisms identified in other countries as helping to tackle exploitative and forced labour. Although sectors and industries with a high risk of the presence of exploitation (Scott et al., 2012) have been identified, and these findings have been integrated into the new Integration Policy, no regulation or monitoring framework has been implemented. Whilst the most vulnerable groups of migrants are known, outreach activities receive no funding and even the work of non-state agencies will probably be reduced after the European Integration Fund dissolves in 2015. A multi-agency approach (Anderson and Rogaly, 2005) to address exploitative labour of migrants is underdeveloped, partly because of the lack of active engagement by some key institutions (such as trade unions, non-active in the area of migrant rights) and partly because of the lack of engagement between migrant communities and the state. The law recognises human trafficking as defined in the Palermo Protocols, but unlike some other West European countries (Skrivankova, 
2010), it does not acknowledge the vulnerability of migrants or define forced labour as a separate offence (FLMG, 2014). Finally, the migration status legislation has been criticised lately and suggestions have been made to liberalise the right to stay, particularly for the most vulnerable migrants (Blazek et al., 2013), yet the political view on migration continues to be among the most restrictive within the EU.

\section{Extent of labour exploitation}

In terms of the overall numbers, the IOM estimated that $11 \%$ of all working adult non-EU migrants in Slovakia have some experience of forced labour and a further $18 \%$ might be at high risk (see Blazek, 2014; the numbers are calculated from ILO [2009] and Skrivankova’s [2010] methodology). The most at-risk group of migrants are Ukrainians, particularly men, who experience forced labour 2-3 times more frequently than other migrants. Despite good general levels of education, these migrants find themselves marginalised, a process fostered by a combination of pressure from those who organise such work (including, especially, confinement, debt bondage or direct threats, see Blazek, 2014), strong motivation to earn money and often subsidise the family in Ukraine, and their intensely suspicious attitude towards formal institutions (the research documented cases of migrants who did not see their children for more than five years, because of travel costs, despite the relative proximity of Slovakia and Ukraine).

However, further indicators of labour exploitation (Scott et al., 2012) show even more signs of labour exploitation: 22\% conduct activities beyond their contract, and more than $41 \%$ work more than 48 hours average per week, the maximum legally-allowed time, including regular work and overtime; and of vulnerability: and 25\% of all working adult non-EU 
migrants do not understand their Slovak contract. As noted, vulnerability rather than deliberate exploitation is more prominent in Vietnamese and Chinese communities. In petty trade, such long hours are worked by both workers and employers and while the workers have little leeway to circumvent this, they usually see it as a normal economic practice rather than exploitation. However, many Vietnamese migrants also work for transnational industrial firms and they most often referred to forced overtimes (under the threat of losing the job) and unpaid salaries among their experiences of exploitation, indicating forced labour practices. As their right to stay depends on their work permit and because of the lack of wider institutional support, they have even fewer opportunities to address this pressure than their Slovak co-workers.

To summarise, work is the key motivation and factor of livelihood for a considerable segment of non-EU migrants in Slovakia. Some groups, particularly migrants from Ukraine and East Asia, are particularly exposed to labour exploitation and forced labour, and their vulnerability is fuelled by two factors: socio-legal and institutional migration contexts in Slovakia, where the state pursues restrictive policies rather than offering support to vulnerable groups; and the importance of ties within migrant communities that privilege certain informal actors, some of whom abuse this position to organise and perpetuate exploitative practices, often together with Slovak partners.

\section{Intersections of violence, abuse and exploitation: migrants and structural violence}

The term structural violence has been used in the literature on migration in various contexts, describing phenomena ranging from the implications of institutional exclusion (Larchanché, 2012) to the structural exposure to the violence of criminal gangs (Slack and Whiteford, 
2011). Two elements are important for understanding the term. First, structural violence is not the same as oppression, as it refers to dynamics which expose victims to actual violence or risk of violence, not just disadvantage, marginalisation or exclusion (Alvarado and Massey, 2010). Secondly, as Galtung (1969) explained in his seminal essay, structural violence is not equal to institutional violence as it entails wider sets of relations associated with one's positionality that encompass more than one institution.

We conducted a Chi-Square test of the relationships between migrants’ experiences with forced labour and other forms of violence: 1 ) hate crime attack in public (verbal or physical); 2) repeated physical attack in public; 3) repeated experience of control by a household member (e.g. of movement, contact, access to money, documents, communication technologies, food, sleep or health care); 4) repeated experience of psychological violence (threats or humiliation) by a household member; and 5) repeated experience of physical violence (including sexual and against property) by a household member. The relationship was in all five cases statistically significant at the 0.01 level, indicating that victims of forced labour are likely also to experience other forms of violence.

Two conclusions from these statistics based on the qualitative findings are important. First, the experience with forced (and exploitative) labour and other forms of violence might be coincidental, but often they are related, and other forms of violence serve as additional methods of control in forced labour situations. For instance, Ukrainian research participants cited a system of accommodation where male migrants working shifts took turns to sleep in a room with a capacity much smaller than was appropriate for the number of people, who were subjected to strict discipline. The violence and control from household members does not refer to intimate partners here, rather to the providers of accommodation associated with the 
employers (see Blazek, 2014), but also to other co-workers, as conflicts and violence are not uncommon in confined spaces (cf. McGrath, 2013). However, we also recorded a situation where a female migrant from Southeast Asia presented her relationship with the employer as intimate, whilst simultaneously declaring experiences with both forced labour and domestic abuse.

On the other hand, even if these experiences are not necessarily related, they indicate that most vulnerable migrant workers are simultaneously exposed to other forms of abuse and have limited capacities to tackle them. Hate-motivated attacks are experienced by migrants from Asian or African countries but also by Ukrainians whose physical appearance is identical to Slovaks, but where differences can be identified by language or accent. Yet with any forms of violence, including incidents not related to migrants' specific position, for example robberies, there is still the additional factor of marginalisation, because most migrants do not trust the police, many do not have the necessary knowledge about their rights and the existing supportive mechanisms, and many are afraid to engage with formal institutions because of threats from their employers or other community members.

These findings suggest that migrant workers in Slovakia are not just vulnerable to exploitative labour, but many are also victims of structural violence. Structural violence is ultimately embodied and manifested in acts of interpersonal violence (Barak, 2003) but it is at the same time systematic, personal and indirect in the sense that it does not necessarily come from a single source, instead being a product of complex socio-economic dynamics, and it targets any member of a certain social group rather than specific individuals (Farmer, 2004). Even those victims of incidents unrelated to their migrant identity might suffer from 
what Quesada et al. (2011) termed ‘structural vulnerability', a lack of means to cope with the difficulties caused by their positionality as migrants.

\section{Conclusions}

The findings from Slovakia suggest an urgent need to focus on experiences of migrants in countries that are normally not seen as 'immigration lands', as even small migrant cohorts might experience profound abuse and exploitation. The case of Slovakia illustrates how emerging migration flows in a country with little history of immigration gave rise to a specific socio-legal and institutional context which nurtured labour exploitation of vulnerable migrants through a lack of institutional engagement and the marginalisation of whole communities.

In addition, the findings show that labour exploitation is often experienced along with other forms of violence, whether in parallel or as their direct component. I discuss this phenomenon through the concepts of structural violence and vulnerability, a system of conditions exposing individuals from certain groups to acts of violence in various spheres of their lives with little capacity to tackle this. Lewis et al. (2014) have suggested a need to rethink the relations between 'precarious work' and 'precarious lives' due to the degree in which precarity exceeds the realm of work. While drawing on a different conceptual tool, I suggest that the problem of migrants' labour exploitation is not just an issue of work, but rather of the broader configurations of migrants' lives from the arena of intimate privacy to their positionality in wider state structures.

\section{Acknowledgment}


The IOM research informing this chapter was funded by the European Integration Fund (Grant nr. SK 2011 EIF P2/1 IP). Soňa Andrášová and Nina Paulenová equally contributed to the completion of the project, but the paper does not necessarily present IOM's views and the IOM takes no responsibility for its content.

\section{Bibliography}

ADP (2014) Statistical Overview of Legal and Illegal Migration in the Slovak Republic. Bratislava: Alien Department Police.

Alvarado SE and Massey DS (2010) In search of peace. structural adjustment, violence, and international migration in Mexico and Central America 1979-2002. The Annals of the American Academy of Political and Social Science 630(1): 137-161.

Anderson B and Rogaly B (2005) Forced Labour and Migration to the UK. London: Trades Union Congress.

Baláž B and Williams AM (2005) Winning, then losing, the battle with globalization: Vietnamese petty traders in Slovakia. International Journal of Urban and Regional Research 29(3): 533-549.

Barak G (2003) Violence and Nonviolence: Pathways to Understanding. London: Sage. Blazek M, Andrášová S and Paulenová N (2013) Skúsenosti Migrantov a Migrantiek na Slovensku s Násilím [Experiences of Migrants in Slovakia with Violence]. Bratislava: International Organization for Migration.

Blazek M (2014) Migration, vulnerability and the complexity of violence: Experiences of documented non-EU migrants in Slovakia. Geoforum 56: 101-112.

Burrell K (eds) (2009) Polish Migration to the UK in the 'New' European Union after 2004. Aldershot: Ashgate. 
Castles S and Miller M (2009) The Age of Migration. International Population Movements in the Modern World. Basingstoke: Palgrave.

Cerna L (2013) Understanding the diversity of EU migration policy in practice: the implementation of the Blue Card initiative. Policy Studies 34(2): 180-200.

Chudžíková A (2011a) Migration strategy: an attempt to homogenize society by 2020? Minority Politics 3/2011: 11-12.

Chudžíková A (2011b) Strategy of integration of foreigners in the Slovak Republic: unclear goals, unclear results. Minority Politics 1/2011: 6-7.

Dwyer P, Lewis H, Scullion L and Waite L (2011) Forced Labour and UK Immigration Policy. Status Matters? York: Joseph Rowntree Foundation.

FLMG (2014) Forced Labour: What Next? Durham: Forced Labour Monitoring Group. Farmer P (2004) An anthropology of structural violence. Current Anthropology 45(3): 305325.

Galtung J (1969) Violence, peace and peace research. Journal of Peace Research 6: 167191.

ILO (2009) The Cost of Coercion. Geneva: International Labour Organization. IOM (2014) Migration in Slovakia, http://www.iom.sk/en/about-migration/migration-inslovakia, date accessed 8 October 2014.

King R (2008) Across the sea and over the mountains. Documenting Albanian migration. Scottish Geographical Journal 119(3): 283-309.

Krings T (2009) A race to the bottom? Trade unions, EU enlargement and the free movement of labour. European Journal of Industrial Relations 15(1): 49-69.

Larchanché S (2012) Intangible obstacles: Health implications of stigmatization, structural violence, and fear among undocumented immigrants in France. Social Science \& Medicine 74(6): 858-863. 
Lewis H, Dwyer P, Hodkinson S and Waite L (2014) Hyper-precarious lives: migrants, work and forced labour in the Global North. Progress in Human Geography, early view. McDowell L (2008) Thinking through work: complex inequalities, constructions of difference and trans-national migrants. Progress in Human Geography 32(4): 491-507. McGrath L (2013) Many chains to break. the multi-dimensional concept of slave labour in Brazil. Antipode 45(4): 1005-1028.

Mrlianová A, Ulrichová N and Zollerová M (2011) Praktické opatrenia v boji proti nelegálnej migrácii v Slovenskej Republike [Practical measures to combat illegal migration in the Slovak Republic] Bratislava: IOM and EMN.

Quesada J, Hart LOK and Bourgois P (2011) Structural vulnerability and health: Latino migrant laborers in the United States. Medical Anthropology: Cross-Cultural Studies in Health and Illness 30(4): 339-362.

Scott S, Craig G and Geddes A (2012) Experiences of Forced Labour in the UK Food Industry. York: Joseph Rowntree Foundation.

Skrivankova K (2010) Between Decent Work and Forced Labour: Examining the Continuum Exploitation. York: Joseph Rowntree Foundation.

Slack J and Whiteford S (2011) Violence and migration on the Arizona-Sorona border. Human Organization 70(1): 11-21.

Vermeersch J (2005) EU enlargement and immigration policy in Poland and Slovakia. Communist and Post-Communist Studies 38(1): 71-88.

White A (2014) Polish return and double return migration. Europe-Asia Studies 66(1): 25-49. Wilkinson M (2014) Demonising 'the other': British Government complicity in the exploitation, social exclusion and vilification of new migrant workers. Citizenship Studies 18(5): 499-515. 
Zubrzycki G (2001) “We, the Polish Nation”: Ethnic and civic visions of nationhood in PostCommunist constitutional debates. Theory and Society 309(5): 629-668. 